\title{
Methyl mercury distributions in relation to the presence of nano- and picophytoplankton in an oceanic water column (Ligurian Sea, North-western Mediterranean)
}

\author{
Lars-Eric Heimbürger ${ }^{\mathrm{a}, \mathrm{b}, \mathrm{c}, *}$, Daniel Cossa ${ }^{\mathrm{a}}$, Jean-Claude Marty ${ }^{\mathrm{b}, \mathrm{c}}$, \\ Christophe Migon ${ }^{\mathrm{b}, \mathrm{c}}$, Bernard Averty ${ }^{\mathrm{d}}$, Aurélie Dufour ${ }^{\mathrm{b}, \mathrm{c}}$, Josephine Ras ${ }^{\mathrm{b}, \mathrm{c}}$ \\ a Ifremer, Centre de Méditerranée, BP 330, F-83507 La Seyne-sur-Mer, France \\ ${ }^{\mathrm{b}}$ Université Pierre et Marie Curie (UPMC), UMR 7093, Observatoire océanologique de Villefranche-sur-Mer, F-06234 \\ Villefranche-sur-Mer, France \\ ${ }^{\mathrm{C}}$ CNRS/INSU, UMR 7093, Laboratoire d'Océanographie de Villefranche-sur-Mer, F-06234 Villefranche-sur-Mer, France \\ ${ }^{\mathrm{d}}$ Ifremer, Centre de Nantes, BP 21105, F-44311 Nantes, France
}

Received 31 December 2009; accepted in revised form 25 June 2010; available online 11 July 2010

\begin{abstract}
Recent findings on the distribution of methylated mercury $\left(\mathrm{MeHg}_{\mathrm{T}}\right)$ in waters have highlighted the importance of organic carbon remineralization on the production of these compounds in the open ocean. Here, we present the first time-series $(20$ monthly samplings between July 2007 and May 2009) of high-resolution vertical profiles (10-12 depths in a $2350 \mathrm{~m}$ water column) of $\mathrm{MeHg}_{\mathrm{T}}$ distributions in an open ocean environment, the Ligurian Sea (North-western Mediterranean Sea). Concentrations varied within the sub-picomolar range (general mean: $0.30 \pm 0.17 \mathrm{pmol} \mathrm{L}^{-1}, n=214$ ) with the lowest values at the surface, increasing with depth up to the oxygen minimum zone, and decreasing slowly at greater depth. Concentrations in the surface waters never exceeded $0.15 \mathrm{pmol} \mathrm{L}^{-1}$, while the highest concentrations (up to 0.82 pmol L $\mathrm{L}^{-1}$ ) were associated to the hypoxycline during the autumn bloom. A detailed vertical $\mathrm{MeHg}_{\mathrm{T}}$ profile reveals a "double-peak" pattern, coincidental with the two microbial layers described by Tanaka and Rassoulzadegan (2002), the so-called "microbial food web" in the euphotic zone $(<100 \mathrm{~m})$ and the "microbial loop" in the aphotic zone $(>100 \mathrm{~m})$. Temporal variations in the $\mathrm{MeHg}_{\mathrm{T}}$ abundance and distribution in the water column were linked to seasonality. The highest $\mathrm{MeHg}_{\mathrm{T}}$ concentrations were found in the oxygen minimum zone during the period of stratification, and coincide with the greatest abundance of nano- and picophytoplankton (cyanobacteria, nanoflagellates, etc.) in the euphotic layer. None of our deep $\mathrm{MeHg}_{\mathrm{T}} \mathrm{measurements}$ ( $\sim 100 \mathrm{~m}$ above the sea bottom) revealed a significant sedimentary source of $\mathrm{MeHg}_{\mathrm{T}}$. We explored the correlation between $\mathrm{MeHg}_{\mathrm{T}}$ concentrations and the apparent oxygen utilization, a proxy of organic matter remineralization, over the study period. Results of this study strengthen the hypothesis that net mercury methylation in the open ocean occurs in the water column, is linked to organic matter regeneration, and is promoted by the presence of small-sized nano- and picophytoplankton, that dominate under oligotrophic conditions.
\end{abstract}

(C) 2010 Elsevier Ltd. All rights reserved.

\footnotetext{
* Corresponding author. Address: Laboratoire des Mecanismes et Transferts en Geologie (LMTG), Midi-Pyrenees Observatory (OMP), 14 Avenue Edouard Belin, 31400 Toulouse, France. Tel.: +335613326 56; fax: +33561332560.

E-mail address: lars-eric.heimburger@lmtg.obs-mip.fr (L.-E. Heimbürger).
}

\section{INTRODUCTION}

Among stable alkyl $\mathrm{Hg}$ species in the environment, monomethyl mercury (MMHg) and dimethyl mercury (DMHg) were identified in open ocean waters in the early 1990s (Mason and Fitzgerald, 1990). MMHg elicits special concern due to its toxicity and its biomagnification in mar- 
ine food chains (e.g., Morel et al., 1998), but its biogeochemical cycle in the ocean is still poorly documented (e.g., Fitzgerald et al., 2007). While it is well established that atmospheric deposition is the primary source of inorganic $\mathrm{Hg}$ to the open ocean, the source(s) of methylated $\mathrm{Hg}$ species $\left(\mathrm{MeHg}_{\mathrm{T}}=\mathrm{MMHg}+\mathrm{DMHg}\right)$ in pelagic environments have been debated for a long time (see review by Fitzgerald et al., 2007). The authors note that neither freshwater inputs (from river or wet atmospheric deposition) nor hydrothermal vent fluids are important sources, but, in addition to sources internal to the water column, diffusion from deep sediments and advection or "bioadvection" of $\mathrm{MeHg}_{\mathrm{T}}$ from near-shore regions may be potential sources. The occurrence of a methylated $\mathrm{Hg}$ maximum in the low oxygen zone of the water column of the open ocean was pointed out 20 years ago (Mason and Fitzgerald, 1990), and hypothesized to result from in situ microbial methylation of inorganic divalent mercury $\left(\mathrm{Hg}^{\mathrm{II}}\right)$. Mason and Fitzgerald (1993) suggested that $\mathrm{DMHg}$ might be a source of $\mathrm{MMHg}$ in the water column, but no clear evidence for this hypothesis has been presented. Recent findings (Cossa et al., 2009; Sunderland et al., 2009), based on high-resolution $\mathrm{MeHg}_{\mathrm{T}}$ profiles, support the hypothesis that internal sources are dominant over advective transport. Positive relationships between $\mathrm{MeHg}_{\mathrm{T}}$ concentrations and apparent oxygen utilization (AOU), and organic carbon remineralization rate (OCRR) have been reported in the open waters of the Mediterranean and the North Pacific (Cossa et al., 2009; Sunderland et al., 2009).

Given that the link between $\mathrm{Hg}$ methylation and organic matter (OM) recycling in the open ocean has been demonstrated, it is reasonable to address the question of its seasonality in response to changes in the type of primary production (PP) and associated regeneration processes. In this paper, we address this question by monitoring the $\mathrm{MeHg}_{\mathrm{T}}$ concentrations within a $2350 \mathrm{~m}$ water column during 20 months, at an oceanic reference station in the Ligu- rian Sea, situated in the North-western Mediterranean. We show that net $\mathrm{Hg}$ methylation in the hypoxic layer of the water column is promoted during oligotrophic periods when PP is dominated by nano- and picophytoplankton.

\section{SITE}

The Dyfamed site (Dynamics of Atmospheric Fluxes in the Mediterranean Sea) is located in the central zone of the Ligurian basin $\left(43^{\circ} 25^{\prime} \mathrm{N}, 7^{\circ} 52^{\prime} \mathrm{E}\right)$ in the North-western Mediterranean Sea (Fig. 1). This site is commonly used as a reference site for atmospheric inputs to an oligotrophic open ocean water column (e.g., Dyfamed and Medflux programs; see special issues Deep-Sea Research II 49 (11), 2002 and 56 (18), 2009, respectively. The offshore central zone of the Ligurian Sea is separated from the coast by the Ligurian current (Fig. 1), across which there is a sharp horizontal density gradient (Sournia et al., 1990; Lévy et al., 1998; Niewiadomska et al., 2008). As a result, the coastal influences of the DyFAmed site should be negligible most of the year, since there are no major rivers flowing into the basin (Copin-Montégut, 1988). Owing to these features and its accessibility ( $\sim 50 \mathrm{~km}$ offshore from Nice), the site was chosen for time-series observations, has been monitored monthly since January 1991, and has been extensively studied for almost three decades (Marty, 2002; Lee et al., 2009, and references therein). The Dyfamed site is regarded as a one-dimensional station where simple hydrological mechanisms prevail and where the ecosystem is well understood (Avril, 2002). Above all, the Ligurian basin is subject to pronounced seasonal variations in hydrology and biology (Marty et al., 2002), with a long stratified period (MayNovember) during which nutrients are depleted in the mixed layer (ML). During this stratified period, atmospheric deposition becomes the major source of trace metals, nutrients, and organic substances to the ML (Migon and Sandroni, 1999; Migon et al., 2002). The vertical stratification is dis-

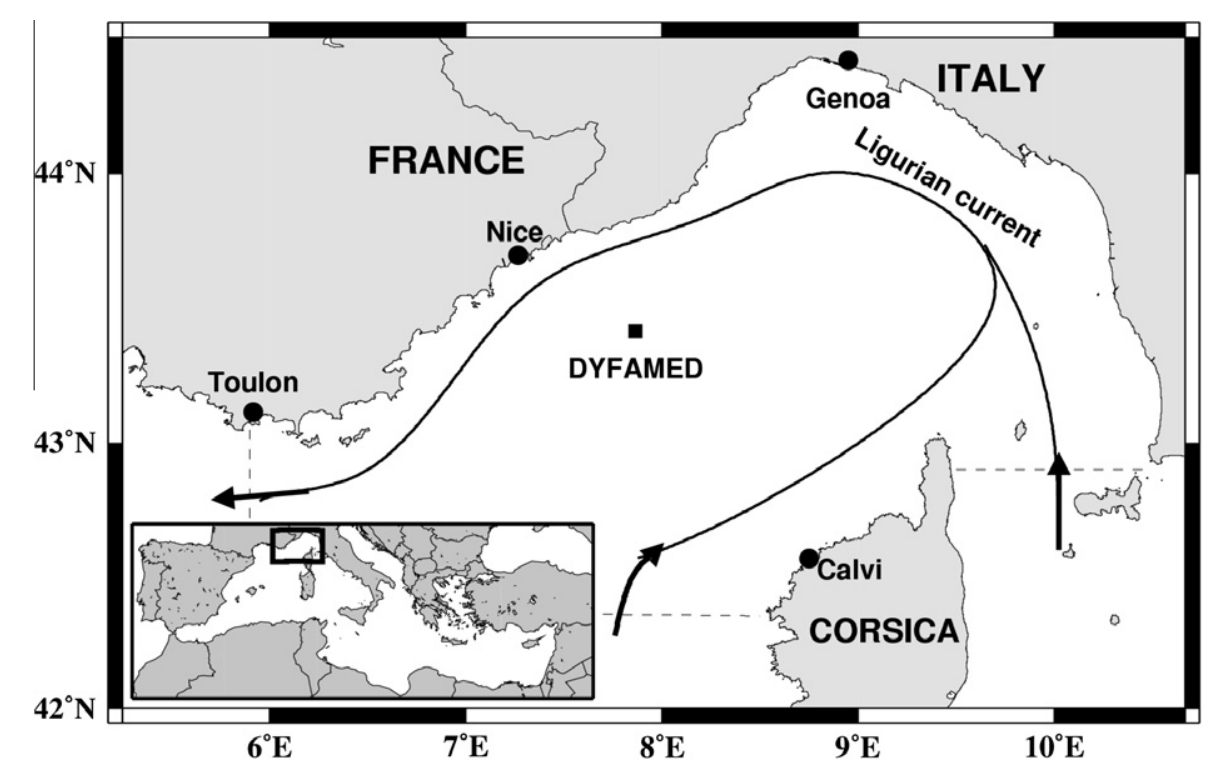

Fig. 1. Dyfamed site in the Ligurian Sea, North-western Mediterranean sheltered from lateral inputs by the persistent Ligurian current. 
rupted by strong winds and low atmospheric temperatures in winter (December-March), lowering the sea surface temperature to $\sim 13{ }^{\circ} \mathrm{C}$ (Marty et al., 2002) and forming dense water. Generally, during dense water formation in February, the mixed layer depth (MLD) reaches its maximum depth of 100-200 m (Marty et al., 2002). Recently, the MLD reached greater depths: 400,700 and $>2000 \mathrm{~m}$ in 2004, 2005 and 2006, respectively (Chiavérini and Marty, 2009). Dense water formation leads to the oxygenation of deep layers, with part of this oxygen being consumed by the remineralization of $\mathrm{OM}$ produced and settling from the euphoric zone. Oligotrophic conditions dominate during the long, stratified period (May-November), when PP values are low, in the range of $0.1-0.3 \mathrm{~g} \mathrm{Cm}^{-2} \mathrm{~d}^{-1}$. Mesotrophy can occur during spring bloom, when PP may reach values up to $1.8 \mathrm{~g} \mathrm{Cm}^{-2} \mathrm{~d}^{-1}$ (Lévy et al., 1998; Marty and Chiavérini, 2002). Seasonal dynamics of phytoplankton abundance were characterized using HPLC pigment measurements (Marty et al., 2002). The 0-200 m integrated total chlorophyll-a concentration ( $\left.\int \mathrm{TChl}-\mathrm{a}\right)$ is highly variable throughout the year and reaches its highest values during the spring bloom (up to $230 \mathrm{mg} \mathrm{m}^{-2}$ ) and, conversely, its lowest values $\left(12 \mathrm{mg} \mathrm{m}^{-2}\right.$ ) during the oligotrophic period (May-November). Diatoms usually dominate the phytoplankton assemblage during the spring bloom, whereas haptophytes are the most abundant group during the rest of the year (Marty et al., 2002). In fact, throughout the year, the phytoplankton biomass is successively composed of mineral-secreting organisms (diatoms) during spring blooms and by mineral-free phytoplankton (dinoflagellates, nanoflagellates, bacterioplankton, etc.) thereafter. The contribution of small-sized phytoplankton, including cyanobacteria, increases at the beginning of summer stratification. As phytoplankton species succeed one another, starting with nutrient-demanding microphytoplankton, such as diatoms, and followed by the smaller, less energy consuming nanoand picophytoplankton, as the nutricline deepens and a deep chlorophyll maximum (DCM) develops at approximately $50 \mathrm{~m}$ depth (Marty et al., 2008).

The total bacterial biomass and production in the euphotic layer in this region is significantly correlated with the phytoplankton biomass (Mevel et al., 2008). Particle attached bacteria are carried down with settling particles and have been associated to high rates of microbial production at depth at the Dyfamed site (Tholosan et al., 1999). Tanaka and Rassoulzadegan (2002), studied the vertical partitioning of microbial trophic structures at the DyFAmED site and found that the consortium of strict heterotrophic microbes becomes more dominant with depth, consistent with the earlier described two-layer microbial ecosystem concept (Rassoulzadegan, 1993). The first layer comprises a "microbial food web" in the euphotic zone $(0-100 \mathrm{~m})$, where bacteria use phytoplankton-derived dissolved organic carbon (DOC) as the primary carbon source. A second layer is situated in the aphotic zone (100-2350 m), usually described as the microbial loop, where particulate organic carbon (POC) delivers DOC as the bacterial carbon source. Dissolved organic carbon accumulates in the ML during summer stratification and is then exported to deeper layers (Copin-Montégut and Avril, 1993; Avril, 2002), fueling the microbial loop. The particle flux was estimated using a mooring line fitted with sediment traps set at 200 and $1000 \mathrm{~m}$ (Miquel et al., 1994; Migon et al., 2002; Miquel et al., 2009) and underwater video profiling (Stemmann et al., 2002) since 1988 and 1992, respectively. Sinking OM is usually constituted of a mixture of phytoplankton detritus, large aggregates formed in the euphotic zone, and zooplankton fecal pellets (Marty et al., 1994). It undergoes remineralization via chemical (e.g., redox-reactions) and bacterial (carried down on particles and free-living deep bacteria) degradation. The high temperatures $\left(\sim 12.9^{\circ} \mathrm{C}\right)$ at depth are responsible for elevated bacterial activity in the Mediterranean, and the relatively homeothermic water column allows to study microbial processes, which are highly sensitive to temperature variations (Tamburini et al., 2003).

\section{MATERIAL AND METHODS}

\subsection{Sampling}

Monthly vertical profiles of $\mathrm{MeHg}_{\mathrm{T}}$ and ancillary parameters were measured over a 20 -month period at the Dyfamed station (Fig. 1) between June 2007 and May 2009, except in December 2008 and February 2009, due to compromising weather conditions. On each cruise aboard the RV Téthys II, water was generally sampled at depths of 3, 10, Chl-a maximum, 50, 100, 200, 400, 600, 1000, 1500, 2000 and $2200 \mathrm{~m}$. Hydrographic parameters were obtained using a CTD profiler (Sea-bird SBE 911plus) with additional sensors (dissolved oxygen and an Aquatracka MKIII Chelsea fluorometer). Water samples were taken using trace-metal clean 5-L Teflon coated external lever action Niskin bottles (General Oceanics 1010X) mounted on a carousel water sampler (Sea-bird SBE32), which was coated with a metal-free epoxy-based paint, to allow trace-clean sampling. Niskin bottles were filled with nitric acid $\left(0.15 \% \mathrm{v} / \mathrm{v}\right.$, Suprapur $\mathrm{HNO}_{3}$ Merck) for $24 \mathrm{~h}$ and rinsed with deionized water (Milli-Q, Millipore) in a clean room (class 100) prior to sampling. Unfiltered samples were collected along the entire water column, while filtered sub-samples were obtained only from the first $50 \mathrm{~m}$ below the surface. Filtrations were performed onboard through filter cartridges (Sartobran 300, $0.2 \mu \mathrm{m}$ ) in line with the Niskin bottles under high-purity nitrogen pressure (11.2 bar) and through filter cartridges. Sub-samples for $\mathrm{MeHg}_{\mathrm{T}}$ measurements were immediately withdrawn into acid-cleaned Teflon (FEP) bottles following trace-metal clean sample handling protocols (Gill and Fitzgerald, 1985). Sub-samples for $\mathrm{MeHg}_{\mathrm{T}}$ were acidified with $\mathrm{HCl}$ $(0.4 \% \mathrm{v} / \mathrm{v}$, Suprapur, Merck). All Teflon bottles were hermetically sealed, double-wrapped in polyethylene bags, and kept at $+4{ }^{\circ} \mathrm{C}$ in the dark to prevent photo-degradation. Special attention was devoted to minimize contamination; all sample handling was done under a laminar flow hood using trace-metal clean techniques, as described elsewhere (Cossa et al., 2004). Water samples for nutrient determination were collected in polypropylene tubes and acidified with $\mathrm{HCl}(0.5 \%, \mathrm{v} / \mathrm{v})$, whereas phytoplankton were collected onto glass-micro fiber filters (GF/F, Whatman) for pigment determination (Ras et al., 2008). 


\subsection{Analyses}

Monomethyl mercury is stable in acidified seawater for at least 250 days, whereas $\mathrm{DMHg}$ rapidly decomposes under similar conditions (Parker and Bloom, 2005). The quantitative conversion of $\mathrm{DMHg}$ into $\mathrm{MMHg}$ in acidified seawater has been recently confirmed (Black et al., 2009). Thus, under our acidic sample storage conditions, the measured $\mathrm{MMHg}$ accounts for both methylated species $\left(\mathrm{MeHg}_{\mathrm{T}}=\mathrm{MMHg}+\mathrm{DMHg}\right)$. Total methylated $\mathrm{Hg}$ was measured on filtered and unfiltered samples as volatile methyl $\mathrm{Hg}$ hydride, by purge and cryo-trapping gas chromatography, and detected as elemental $\mathrm{Hg}$ vapor by atomic fluorescence spectrometry (Tekran, Model 2500). The analytical protocol was designed by Stoichev et al. (2004) and detailed by Cossa et al. (2009). The hydrides are formed within a glass reactor and the column used is a glass tube filled with Chromosorb W/AW-DMCS impregnated with $15 \%$ OV-3. The analytical reproducibility was approximately $15 \%$, whereas the detection limit was $0.04 \mathrm{pmol} \mathrm{L}^{-1}$. Accuracy was checked using the certified reference material (CRM) ERM-AE670 $\left(\mathrm{CH}_{3}{ }^{202} \mathrm{HgCl}\right.$ in $2 \%$ ethanol/water, IRMM, European Commission). Dissolved oxygen was measured in situ by a SBE-43 sensor mounted on the CTD probe. Each profile was recalibrated with data obtained from discrete samples, titrated following the standard Winkler method. Soluble reactive phosphate (SRP) concentrations were determined by an auto-analyzer using the standard molybdate blue method, according to the protocol developed by Aminot and Kérouel (2007).

Pigment determination was performed using high performance liquid chromatography (HPLC) techniques described in Ras et al. (2008). A method proposed by Claustre (1994) and further improved by Vidussi et al. (2001) and Uitz et al. (2006) was used to estimate the contribution of three pigment-based size classes to the total phytoplankton biomass: micro- $(>20 \mu \mathrm{m})$, nano- $(2-$ $20 \mu \mathrm{m})$, and picophytoplankton $(<2 \mu \mathrm{m})$. Total chlorophyll-a is the sum of chlorophyll-a + divinyl-chlorophyll-a concentrations. The position of the MLD was estimated using the density gradient limit of $0.05 \mathrm{~kg} \mathrm{~m}^{-3}$ between the surface $(10 \mathrm{~m})$ and the base of the ML (Lévy et al., 1998). The apparent oxygen utilization was calculated as the difference between the measured and saturated dissolved oxygen concentrations for a given temperature and salinity, according to the equation of Benson and Krause (1984).

\section{RESULTS AND DISCUSSION}

\subsection{Hydrological and biological seasonal patterns}

The salinity and temperature distributions follow the typical pattern found at the site during the seasonal cycle (Marty et al., 2002). Nevertheless, we noticed a slight increase in both parameters in the Western Mediterranean Deep Water (WMDW), as previously reported by Béthoux et al. (1990). Salinity values ranged from 38.02 to 38.62 , with vertical profiles reaching lowest values in the ML, maximum values between 200 and $600 \mathrm{~m}$ (Levantine inter- mediate water-LIW), and moderate values below $600 \mathrm{~m}$ (WMDW). Temperature ranged from 12.89 to $24.65^{\circ} \mathrm{C}$, with highest values in the shallow ML $(\sim 10 \mathrm{~m})$ at the end of summer. Vertical temperature profiles converge below $1000 \mathrm{~m}$ to approximately $12.9^{\circ} \mathrm{C}$, while the overlying LIW is slightly warmer at approximately $13.4^{\circ} \mathrm{C}$. Potential density and MLD seasonal patterns during the sampling period are shown in Fig. 2a. The water column remained well stratified most of the time, and only slight winter mixing occurred. In contrast to the usual MLDs of 100-200 m (Marty et al., 2002) or more ( $>2000 \mathrm{~m}$ in 2006; Chiavérini and Marty, 2009) during winter mixing in this region, the MLDs never exceeded $70 \mathrm{~m}$ (Fig. 2a).

Biological parameters varied widely over the sampling period. Total chlorophyll-a (TChl-a) distributions revealed spring and autumn phytoplankton blooms within the upper $50 \mathrm{~m}$ (Fig. 3a). Total integrated chlorophyll-a concentrations, calculated within the upper $200 \mathrm{~m}$, ranged from 20 to $156 \mathrm{mg} \mathrm{m}^{-2}$, similar to those usually found (12$230 \mathrm{mg} \mathrm{m}^{-2}$ ) at this site (Marty et al., 2002). These authors described an increase of $\int$ TChl-a from 1991 to 1999 . The observed temporal increase in concentration seems to persist, with a mean $\int \mathrm{TChl}-\mathrm{a}$ concentration in 2007-2009 around $60 \mathrm{mg} \mathrm{m}^{-2}$, i.e., approximately $20 \%$ higher than ten years ago. Exceptionally high $\int \mathrm{TChl}-\mathrm{a}$ concentrations $\left(62 \mathrm{mg} \mathrm{m}^{-2}\right)$ were measured in October 2007, whereas, according to Marty et al. (2002), who conducted a time-series starting in 1991, concentrations of $10-30 \mathrm{mg} \mathrm{m}^{-2}$ were generally observed during this season of the year. This might be attributed to either a nutrient-enriched atmospheric event (Bartoli et al., 2005), or a slight deepening of the ML (Fig. 2a) following a wind event (Andersen and Prieur, 2000), or both, introducing nutrients in the ML and generating a so-called autumn bloom. The isolation of the ML from the underlying water mass, combined with the very low PP, leads to an accumulation of atmospherically derived matter (Migon et al., 2002) and DOC (Avril, 2002) during the stratified period (May-November). Hence, one would expect a high downward export of elements, including $\mathrm{Hg}$, after the accumulation during the summer stratification period. In addition to TChl-a, a proxy of total phytoplanktonic biomass, the pigment-based size class method provides information about the phytoplankton size spectrum (Fig. 3b-d). Microphytoplankton (essentially diatoms) were associated with the spring bloom period, whereas nano- and picophytoplankton (mostly cyanobacteria, chrysophytes and prymnesiophyte nanoflagellates) abundance peaked during the oligotrophic stratified period and autumn blooms (Fig. 3a-d).

Typical of this area (Copin-Montégut and Begovic, 2002), dissolved oxygen concentrations ranged from 168 to $302 \mu \mathrm{mol} \mathrm{L}^{-1}$, with the lowest concentrations in the LIW, converging towards $200 \mu \mathrm{mol} \mathrm{L}^{-1}$ below $1250 \mathrm{~m}$. This distribution is consistent with the bacterial count and bacterial production profiles, which classically decrease with depth but show a peak between 300 and $400 \mathrm{~m}$ where AOU is maximal at this site (Tamburini et al., 2002). The AOU profiles are given in Electronic Annexes 1 and 2.

Fig. $2 b$ presents the vertical SRP distribution of the entire water column for the whole sampling period. The SRP 

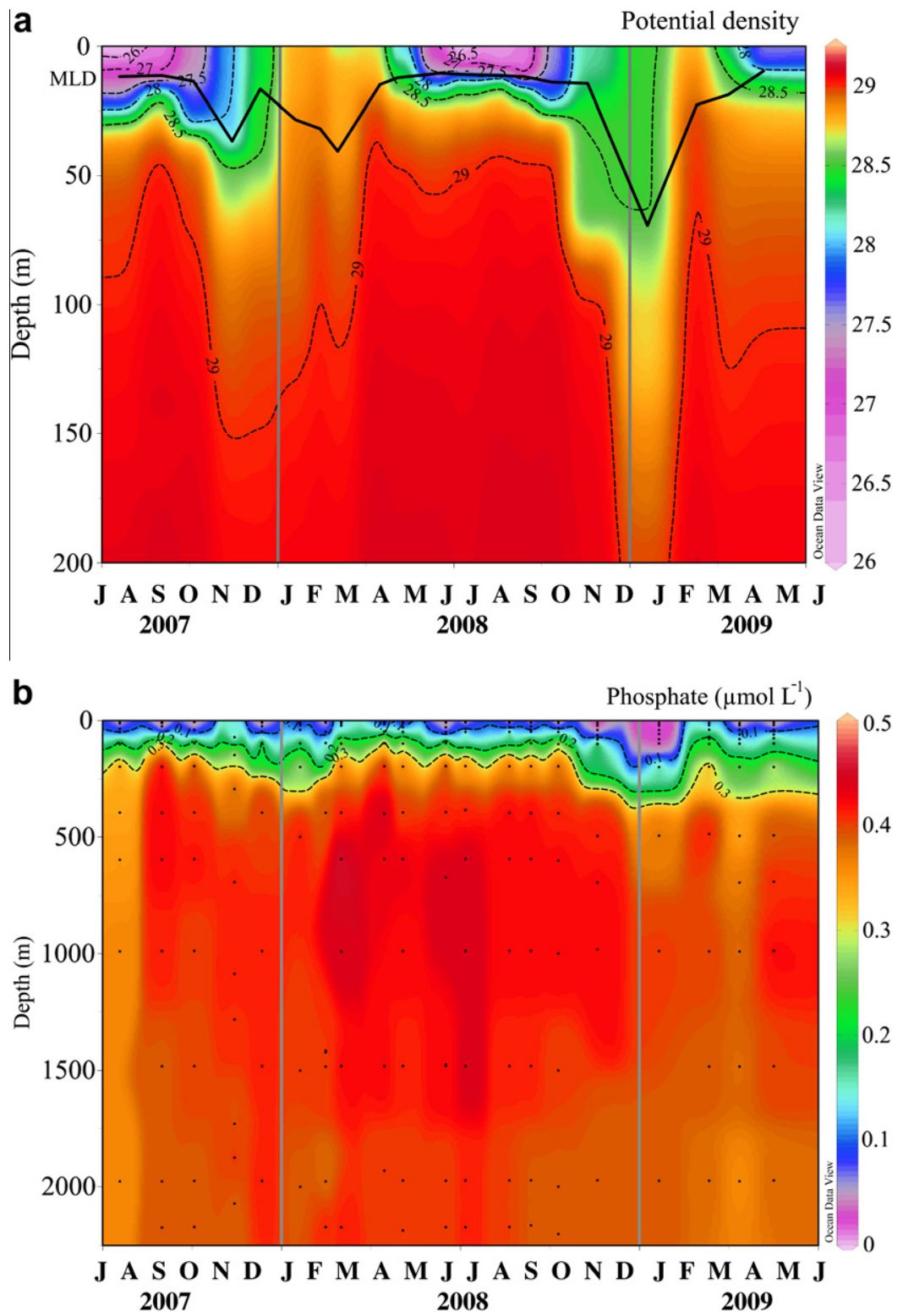

Fig. 2. (a) Potential temperature and (b) soluble reactive phosphate vertical distributions in the 2350-m deep water column during the sampling period of July 2007-May 2009.

profiles were typical of the distribution usually observed at the DyFamed site (Marty et al., 2002), with the highest concentrations between 500 and $1000 \mathrm{~m}$, especially between March and July 2008 (Fig. 2b), and the lowest concentrations in the surface layer. Deepening of the ML in February 2008 and 2009 (41 and 69 m, respectively; Fig. 2a) lead to a partial homogenization after which slightly higher SRP concentrations were present in the ML (March 2008 and 2009; Fig. 2b).

In summary, our sampling period from mid-2007 to mid-2009 displayed (i) a highly stratified water column with slight dense water convection in winter, (ii) phytoplankton blooms in spring and late summer-early autumn (especially autumn 2007) and (iii) a peak abundance of nano- and picophytoplankton in this latter season, favoring subsequent $\mathrm{OM}$ regeneration in both microbial food web and loop.

\section{2. $\mathrm{MeHg}_{\mathrm{T}}$ concentration levels}

Since no significant differences in $\mathrm{MeHg}_{\mathrm{T}}$ concentration were observed between the filtered and unfiltered samples, only data obtained with unfiltered seawater are presented. Summary statistics of $\mathrm{MeHg}_{\mathrm{T}}$ concentrations are given in Table 1 whereas the whole profiles can be found in Electronic Annex 1. The most striking feature was the wider range of concentrations obtained during this time-series (from the detection limit to $0.82 \mathrm{pmol} \mathrm{L}^{-1}$ ) than reported from earlier single cruise measurements in various sub-basins of the Western Mediterranean (Kotnik et al., 2007; Cossa et al., 2009). Nevertheless, when compared to the mean $\mathrm{MeHg}_{\mathrm{T}}$ value obtained at a nearby station occupied during a previous cruise, west of Corsica (Sta. 2 from Cossa et al. (2009), depth $2600 \mathrm{~m}$ ), the discrepancy is minor 

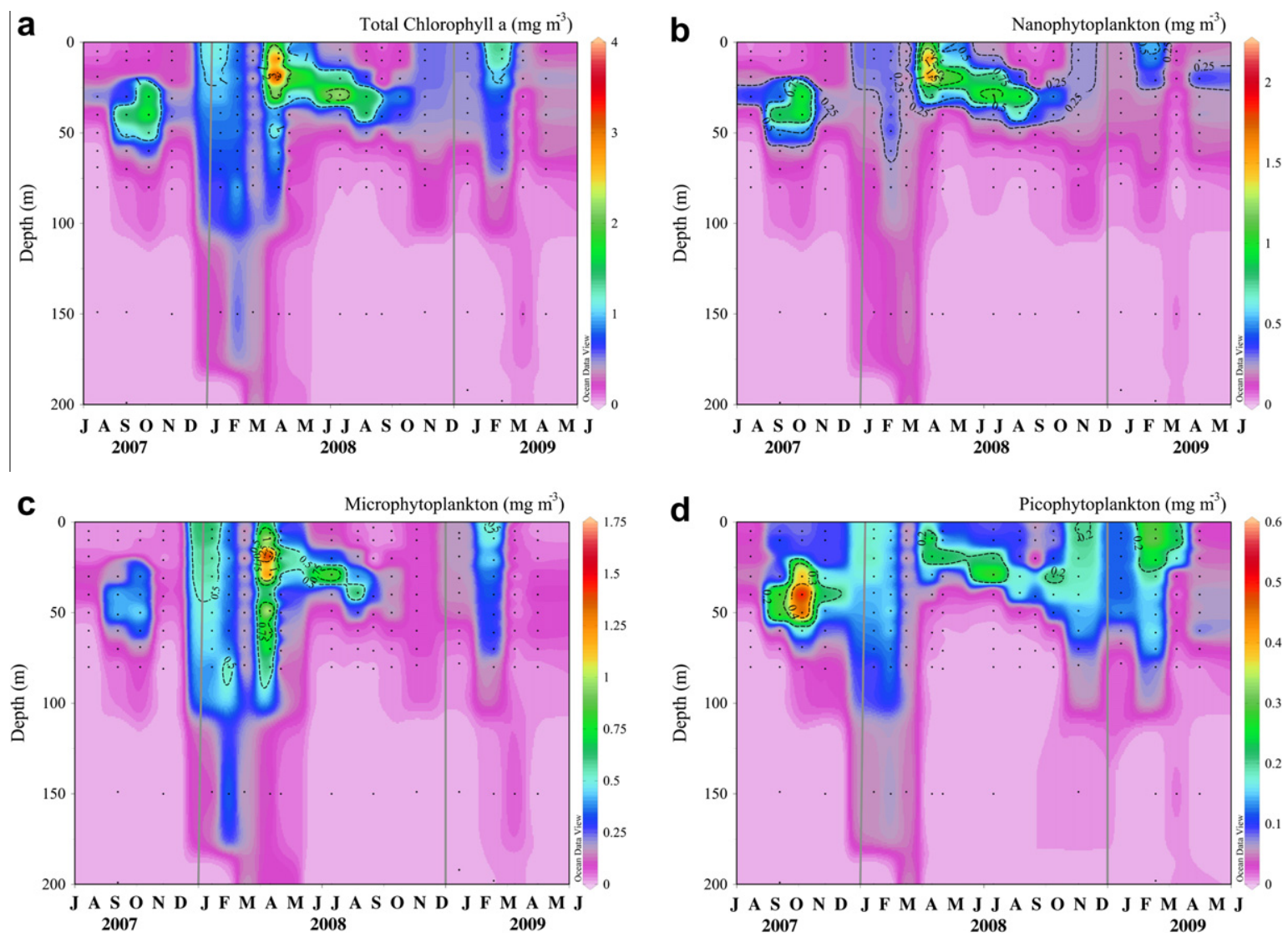

Fig. 3. (a) Total chlorophyll-a, (b) microphytoplankton, (c) nanophytoplankton and picophytoplankton vertical distributions in the upper $200 \mathrm{~m}$ during the sampling period of July 2007-May 2009.

Table 1

Summary statistics of $\mathrm{MeHg}_{\mathrm{T}}$ concentrations $\left(\mathrm{pmol} \mathrm{L}^{-1}\right.$ ) in various depth layers of the water column sampled monthly from July 2007 to May 2009 at the DyFamed site.

\begin{tabular}{|c|c|c|c|c|c|c|c|c|}
\hline Depth (m) & Zone & Arithmetic mean & Standard deviation & Median & Geometric mean & $N$ & Minimum & Maximum \\
\hline $0-10$ & Surface & 0.07 & 0.03 & 0.07 & 0.07 & 29 & $\leqslant 0.04^{*}$ & 0.15 \\
\hline $10-100$ & Microbial food web & 0.22 & 0.11 & 0.20 & 0.17 & 60 & 0.05 & 0.48 \\
\hline $100-1500$ & Microbial loop & 0.42 & 0.14 & 0.42 & 0.39 & 94 & 0.09 & 0.82 \\
\hline $1500-2200$ & Bottom zone & 0.29 & 0.12 & 0.28 & 0.27 & 30 & 0.10 & 0.52 \\
\hline $0-2200$ & Total & 0.30 & 0.17 & 0.29 & 0.24 & 214 & $0.04^{*}$ & 0.82 \\
\hline
\end{tabular}

Zones are defined according to Tanaka and Rassoulzadegan (2002).

* Detection limit.

$\left(0.24 \pm 0.15 \mathrm{pmol} \mathrm{L}^{-1}\right.$ at Sta. 2 compared to $0.30 \pm 0.17$ pmol L ${ }^{-1}$ at DyFAMED). The present time-series (214 analyses over a 20-month sampling period) allowed us to assess various seasonal scenarios, including those most favorable to $\mathrm{Hg}$ methylation. The wide range of $\mathrm{MeHg}_{\mathrm{T}}$ concentrations reported in this study reflects both spatial (depth) and temporal variabilities.

\section{3. $\mathrm{MeHg}_{\mathrm{T}}$ vertical distributions}

All vertical $\mathrm{MeHg}_{\mathrm{T}}$ profiles exhibited roughly the same pattern: the lowest concentrations are observed in the surface layer $(0-10 \mathrm{~m})$, occasionally a sub-surface peak ap- pears in the productive euphotic zone $(20-80 \mathrm{~m})$ whereas high concentrations are found in the aphotic zone, including a well defined maximum in the regeneration zone (200-1000 m), and a slight decrease down to the bottom layer (Fig. 4a and Electronic Annex 1). The large standard deviations of the $\mathrm{MeHg}_{\mathrm{T}}$ means reported for each sampling depth in Fig. 4a testify of the large amplitude of seasonal variations. Vertical profiles with low surface concentrations and a broad peak at depth have already been observed in the Mediterranean (Cossa et al., 1994, 1997; Horvat et al., 2003; Cossa and Coquery, 2005; Kotnik et al., 2007). This pattern reflects a steady state between methylation and demethylation in the water column. The low $\mathrm{MeHg}_{\mathrm{T}}$ con- 
centrations generally encountered in marine surface waters of the Mediterranean Sea might be, according to Horvat et al. (2003), a result of its efficient photochemical and microbial decomposition, whereas the maximum at depth would be, according to Mason and Fitzgerald (1990), the result of in situ $\mathrm{Hg}$ methylation mediated by bacterial activity. Demethylation of $\mathrm{MeHg}_{\mathrm{T}}$, as waters age, seems responsible for the $\mathrm{MeHg}_{\mathrm{T}}$ distribution in the deep waters (Cossa et al., 2009; Sunderland et al., 2009). Specific to our observations is the occurrence of occasional more or less distinct peaks within the euphotic zone, namely in July and December 2007, January, February, July and September 2008, as well as March and May 2009 (Electronic Annex 2). Even in the absence of a distinct peak, an increase of $\mathrm{MeHg}$ in the euphotic zone is observed in September and October 2007, and August and October 2008. Because of its position in the water column, one might think that this structure is related to the presence of phytoplankton but no statistically significant relationship was found between $\mathrm{MeHg}_{\mathrm{T}}$ and fluorescence. Instead, heterotrophic microbial activity associated with phytoplankton (the microbial food web) could be implied. Furthermore, the $\mathrm{MeHg}_{\mathrm{T}}$ peak in the euphotic zone could be interpreted as evidence of $\mathrm{Hg}$ methylation in Mediterranean surface waters, as previously asserted by Monperrus et al. (2007) based on data obtained from stable $\mathrm{Hg}$ isotope incubation experiments. This interpretation is supported by the absence of significant differences between $\mathrm{MeHg}_{\mathrm{T}}$ concentrations in the filtered and unfiltered samples collected from the euphotic zone, implying that most of the $\mathrm{MeHg}_{\mathrm{T}}$ is present in the dissolved $(<0.45 \mu \mathrm{m})$ phase, an indication of local methylmercury production. The double-peak feature observed for the first time in the water column evokes the two microbial layer system described by Tanaka and Rassoulzadegan (2002). The first layer is situated in the aphotic zone $(>100 \mathrm{~m})$, usually described as the microbial loop, where POC delivers DOC as the bacterial carbon source. The second comprises, according to the same authors, a "microbial food web" in the euphotic zone $(<100 \mathrm{~m})$, where bacteria use phytoplankton-derived DOC as the principal carbon source. These observations and interpretations are consistent with results of incubation experiments in which trace additions of stable $\mathrm{Hg}$ isotopes revealed that oxic surface Mediterranean waters may serve as a site of $\mathrm{Hg}$ methylation (Monperrus et al., 2007). Since
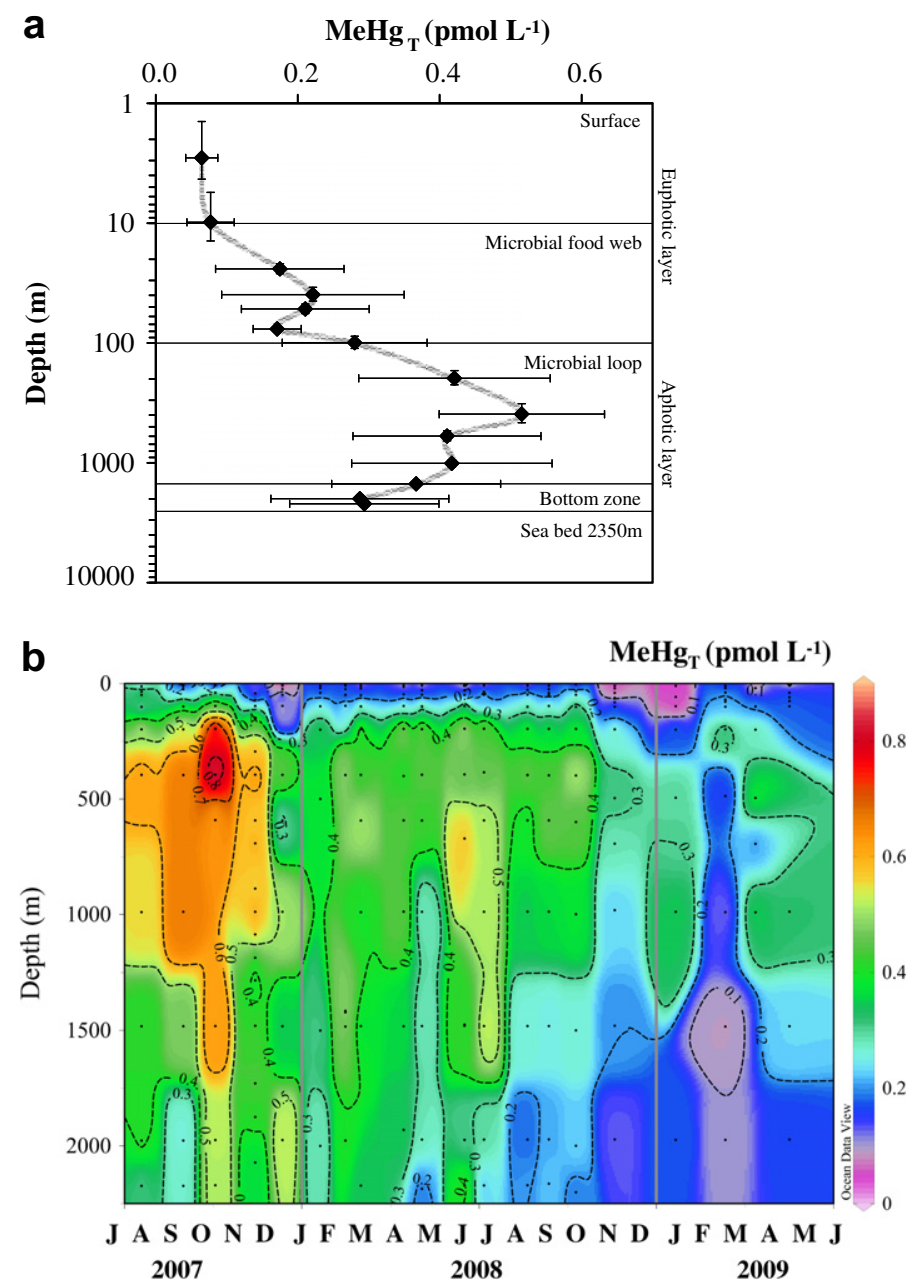

Fig. 4. (a) Mean vertical $\mathrm{MeHg}_{\mathrm{T}}$ profile derived (b) $\mathrm{MeHg}_{\mathrm{T}}$ vertical distributions in the $2350-\mathrm{m}$ deep water column during the sampling period of July 2007-May 2009. 
sediments are also believed to be a $\mathrm{MeHg}_{\mathrm{T}}$ source to Mediterranean offshore waters (Ogrinc et al., 2007), we closely examined the deeper part of our profiles. None of our deep $\mathrm{MeHg}_{\mathrm{T}}$ measurements $(\sim 100 \mathrm{~m}$ above the sea bottom) show a significant increase in concentration near the bottom, in contrast to previous observations in the Mediterranean (Kotnik et al., 2007). In fact, we observed lower values in the bottom layer (1500-2200 m; $0.29 \pm 0.12 \mathrm{pmol} \mathrm{L}^{-1}$, Table 1) than in the intermediate layers $(100-1500 \mathrm{~m}$; $0.42 \pm 0.14 \mathrm{pmol} \mathrm{L}^{-1}$, Table 1). Consequently, significant sedimentary sources of $\mathrm{MeHg}_{\mathrm{T}}$ to the water column at the Dyfamed site can be ruled out.

\section{4. $\mathrm{MeHg}_{\mathrm{T}}$ and organic carbon remineralization}

All vertical $\mathrm{MeHg}_{\mathrm{T}}$ profiles (Fig. 4b) exhibited nutrientlike distributions within the first $600 \mathrm{~m}$. Total methylated $\mathrm{Hg}$ and SRP concentrations are significantly correlated $\left(\mathrm{MeHg}_{\mathrm{T}}=0.89 \mathrm{SRP}+0.077, R^{2}=0.45, n=126, p<0.01\right)$ at the DyFAmed site. Cossa et al. (2009) found a comparable correlation for a station (Sta. 2 in the Alegro-Provencal basin; $\mathrm{MeHg}_{\mathrm{T}}=1.00 \mathrm{SRP}+0.037, \quad R^{2}=0.96, \quad n=6$, $p<0.01$ ) close to the DyFAmed site, underlining the robustness of this relationship. This pattern, also observed in other regions of the Mediterranean Sea (Cossa et al., 2009) and the Northern Pacific (Sunderland et al., 2009), indicates that $\mathrm{MeHg}_{\mathrm{T}}$ formation is linked to the organic carbon remineralization process. In order to test the role of POC remineralization, on the production of $\mathrm{MeHg}_{\mathrm{T}}$, we explored the relationship between $\mathrm{MeHg}_{\mathrm{T}}$ and the AOU within the first $600 \mathrm{~m}$ (monthly AOU profiles are given in Electronic Annex 1). Nineteen of the 20 correlation coefficients for each of the monthly relationships are significant $(p<0.05)$ whereas 14 are highly significant $(p<0.01)$, and regression coefficients range from 0.0020 to $0.0133 \mathrm{pmol}_{\mathrm{MeHg}} \mu \mathrm{mol}_{\text {Oxy }}$ (Electronic Annex 3). This range encompasses values obtained by Cossa et al. (2009) for the Algero-Provencal, Tyrrhenian and Ionian basins (0.0021-0.0044 with a mean value of 0.0039 pmol$\left.\mathrm{MeHg}: \mu \mathrm{mol}_{\text {Oxy }}\right)$. Interestingly, the linear regression coefficient we obtain between $\mathrm{MeHg}_{\mathrm{T}}\left(\mathrm{pmol} \mathrm{L}^{-1}\right)$ and $\mathrm{AOU}\left(\mu \mathrm{mol} \mathrm{L}{ }^{-1}\right)$ $\left(\mathrm{MeHg}_{\mathrm{T}}=0.0040 \mathrm{AOU}+0.014, R^{2}=0.53 ; n=137, p<\right.$ 0.01 ) is similar to that calculated by Cossa et al. (2009) at Sta. 2, located West of Corsica, a station located close to the Dyfamed site $\left(\mathrm{MeHg}_{\mathrm{T}}=0.0044 \mathrm{AOU}+0.0645\right.$, $\left.R^{2}=0.95 ; n=10, p<0.01\right)$. The slopes of the monthly relationships within the first $600 \mathrm{~m}$ varied with more than 3-fold (Electronic Annex 3), indicating a highly variable "Hg net methylation efficiency" with the seasons. This seasonal variation may result from changes in photochemical and microbial decomposition of $\mathrm{MeHg}_{\mathrm{T}}$ in surface water and microbial methylation and demethylation rates at depth. In the absence of quantitative estimates of irradiance, $\mathrm{Hg}^{\mathrm{II}}$, and methyl radical availability, we focus on the phytoplankton, the origin of $\mathrm{OM}$ which is exported and fuels the microbial activity at depth.

\section{5. $\mathrm{MeHg}_{\mathrm{T}}$ and phytoplankton seasonality}

Temporal variations in $\mathrm{MeHg}_{\mathrm{T}}$ abundance and distribution in the water column are clearly linked to seasonal con- ditions. High $\mathrm{MeHg}_{\mathrm{T}}$ concentrations occurred in late summer/autumn 2007, with a maximum in October, early summer 2008, and at the end of the sampling period in May 2009. These periods correspond to specific episodes of primary producer development in the water. They do not correspond to the most productive periods, shown by the TChl-a distribution (Fig. 3a), but coincide with the episodes of highest abundance of nano- and picophytoplankton, including cyanobacteria and nanoflagellates (Fig. 3c and d). Nano- and picophytoplankton may favor $\mathrm{Hg}$ methylation because they accumulate more efficiently particlereactive trace metals, especially $\mathrm{Hg}$, because of their greater surface/volume ratio compared to microphytoplankton (Fisher, 1985) and, thus, they provide more substratum for methylation at depth. It has been shown by Mevel et al. (2008) that the total bacterial biomass and production in the euphotic layer near the DyFAMED station is significantly correlated with the phytoplanktonic biomass. Furthermore, it is well established that small phytoplankton (nano- and picophytoplankton) have a lower sinking velocity, and, thus, a longer residence time in the water column (Cuny et al., 2002; Guidi et al., 2009; Wakeham et al., 2009). According to these authors, small phytoplankton are grazed by small microzooplankton, whose fecal pellets also sink more slowly than those produced by larger zooplankton. Moreover, the authors state that the longer residence time favors the microbial degradation of sinking OM in the water column. Hence, OM generated mostly during the autumn blooms promotes microbial degradation and transformation (Tamburini et al., 2003). These findings are consistent with the hypo put forth by Karl et al. (1988) that large sinking particles are, in general, poor habitat for bacterial growth and, therefore, unlikely sites for active remineralization of $\mathrm{OM}$. The microbial population associated to picophytoplankton may constitute a better environment for microbial decomposition of settling particles and, possibly, bacterial $\mathrm{Hg}$ methylation. On the other hand, our AOU data do not attest to an increase in the heterotrophic activity during and/or after the autumn bloom, leading us to hypothesize that the major factor controlling the seasonal variation of the net microbiological methylation of $\mathrm{Hg}$ in the water column is rather the $\mathrm{Hg}$ bioavailability, promoted by $\mathrm{Hg}$ enrichment in the small-sized phytoplankton (Fisher, 1985) rather than the intensity of the heterotrophic activity.

Conversely, the lowest $\mathrm{MeHg}_{\mathrm{T}}$ concentrations were measured in winter (December-March) (Fig. 4b), upon dense water formation and homogenization of the water column (Fig. 2a), hampering biological activity (Fig. 3a). We believe that subsequent spring blooms did not lead to high $\mathrm{MeHg}_{\mathrm{T}}$ concentrations for two reasons. Firstly, high fluxes of large diatom detritus, with high sinking velocity, generated relatively small ectoaminopeptidase activity (EAA; a proxy for bacterial activity) in spring (during the mesotrophic conditions) whereas, in autumn (during oligotrophic conditions), a smaller flux of "older" OM generates higher EAA (Tamburini et al., 2003). In other words, in oxic oceanic waters, a spring diatom bloom leads to a high flux of rapidly sinking, organically "fresh" aggregates and zooplankton fecal matter, whereas oligotrophy is character- 
ized by a higher proportion of slowly sinking, un-aggregated picophytoplankton cells that are more readily degraded by bacteria within the water column (Guidi et al., 2009; Wakeham et al., 2009), promoting $\mathrm{Hg}$ methylation. Secondly, such "fresh" OM of the spring bloom should be less enriched in $\mathrm{Hg}$ than "older" Om settling through the water column in the autumn after a long stratification period. Alternatively, seasonal changes in $\mathrm{MeHg}_{\mathrm{T}}$ could reflect changes in microbial community composition on sinking particles, driven by changes in phytoplankton community, with a shift to microbes with higher $\mathrm{Hg}$ methylation potentials in the autumn. Nevertheless, this scenario is less likely since, according to Tanaka and Rassoulzadegan (2002): "All microbial heterotrophs were always distributed down to $2000 \mathrm{~m}$ " at DyFAmed site.

\section{SUMMARY AND CONCLUSIONS}

The time-series of deep water $\mathrm{MeHg}_{\mathrm{T}}$ profiles generated in the Ligurian Sea (North-western Mediterranean), an analogue of an open ocean environment, show systematic vertical patterns with lowest $\mathrm{MeHg}_{\mathrm{T}}$ concentrations in the surface layer, a small sub-surface peak in the productive euphotic zone, the highest concentrations in the aphotic zone, and a slight decrease down to the bottom layer (Fig. 4a). The amplitude of the $\mathrm{MeHg}_{\mathrm{T}}$ peaks varied seasonally with the highest concentration observed during the autumn bloom, when phytoplankton communities were dominated by nano- and picophytoplankton species. The vertical pattern does not show any evidence of external sources and is thought to reflect a methylation-demethylation steady state in the water column. It also reflects the existence of two distinct methylation zones associated with two different heterotrophic active layers, namely the "microbial food web" and the "microbial loop" in the euphotic and aphotic zone respectively, as defined by Tanaka and Rassoulzadegan's typology (2002). Essentially, the vertical distributions of $\mathrm{MeHg}_{\mathrm{T}}$ and phytoplankton suggest that oligotrophic conditions, dominated by nano- and picophytoplankton and enhancing microbial loop activity in autumn, favor $\mathrm{Hg}$ methylation at depth. In contrast, the $\mathrm{MeHg}_{\mathrm{T}}$ distributions in surface and bottom waters are consistent with the current paradigms (Sunderland et al., 2009) that photochemical and biological demethylation maintain low concentration in surface and in deep waters, respectively.

Since this work provides additional evidence of the strong relationship between $\mathrm{Hg}$ methylation processes and the organic carbon cycle in the ocean, we allow ourselves to speculate on the possible effects of anthropogenic and climatic changes on the $\mathrm{MeHg}_{\mathrm{T}}$ formation in the open Mediterranean Sea, independently of inorganic $\mathrm{Hg}$ deposition scenarios. In the Mediterranean basins it is generally accepted that oligotrophy could increase as temperatures increase and lengthen the stratification period, promoting the proliferation nano- and picophytoplankton (Marty et al., 2002). Bartoli et al. (2005) hypothesized that anthropogenic nitrate and phosphate inputs to the Mediterranean may also increase in the future, while silicate inputs remain relatively constant. This would promote a preferential pro- liferation of the nano- and picophytoplankton, at the expense of siliceous microphytopankton, e.g., diatoms (Béthoux et al., 2002; Marty et al., 2002; Béthoux and Migon, 2009), conditions conducive to enhanced $\mathrm{Hg}$ methylation. In addition, higher water temperatures $\left(>12.9^{\circ} \mathrm{C}\right)$ will lead to higher bacterial activity (Tanaka and Rassoulzadegan, 2004) and, in turn, to high $\mathrm{Hg}$ methylation rates in the water column, as suggested earlier by Bacci (1989) for sediments. Recent data, which show further increase of WMDW temperatures (Chiavérini and Marty, 2009), also suggest that $\mathrm{Hg}$ methylation in the water of the Mediterranean Sea may increase in the future. Indeed, the warming trend of WMDW, described by Béthoux et al. (1990) (i.e., $0.04{ }^{\circ} \mathrm{C}$ per 10 years for the period of $1959-1989$ ), is confirmed by recent observations (Marty and Chiavérini, 2010).

Finally, from an ecological point of view, our finding that net $\mathrm{Hg}$ methylation in the open ocean is promoted by the presence of nano- and picophytoplankton, that dominate under oligotrophic conditions, is consistent with the hyperbioaccumulation of methyl mercury in the Mediterranean top predatory animals discovered more than 25 years ago (see review by Aston and Fowler, 1985). It can be reasonably speculated that high methylmercury biomagnification in oligotrophic Mediterranean food webs is favored by higher methylmercury incorporation by the microbial food web (Kainz and Mazumder, 2005), and higher bioamplification due to the longer food web (Cabana and Rasmussen, 1994), compared to ecosystems based on microphytoplankton.

\section{ACKNOWLEDGMENTS}

This research was supported by the IFREMER project Medicis (Mediterranean Contaminants Identification System) and the PACA Region, with the participation of the "Agence de l'Eau Rhône-Méditerranée-Corse". We would like to thank the captain and crew of the R/V TeThys II, Céline Bachelier, Gaël Durrieu, Grigor Obolensky and Vincenzo Vellucci for their work at sea. We are also grateful to the Boussole project, Laurent Coppola (Service d'Observation du Laboratoire d'Océanographie de Villefranche), Francis Louis and Roger Kerouel (Ifremer, Centre de Brest). Finally, we would like to thank the three reviewers and the Associate Editor, Dr. A. Mucci for their thorough review and their constructive comments which greatly improved our manuscript.

\section{APPENDIX A. SUPPLEMENTARY DATA}

Supplementary data associated with this article can be found, in the online version, at doi:10.1016/ j.gca.2010.06.036.

\section{REFERENCES}

Aminot A. and Kérouel R. (2007) Dosage automatique des nutriments dans les eaux marines: méthodes en flux continu. MEDD and Quae Publishers, France, ISBN: 10 275920023X, $188 \mathrm{p}$.

Andersen V. and Prieur L. (2000) One-month study in the open NW Mediterranean Sea (DYNAPROC experiment, May 1995): 
overview of the hydrobiogeochemical structures and effects of wind events. Deep Sea Res. I 47, 397-422.

Aston S. R. and Fowler S. W. (1985) Mercury in the Open Mediterranean - evidence of contamination? Sci. Total Environ. 43, 13-26.

Avril B. (2002) DOC dynamics in the northwestern Mediterranean Sea (DYFAMED site). Deep Sea Res. II 49, 2163-2182.

Bacci E. (1989) Mercury in the Mediterranean. Mar. Pollut. Bull. 20, 59-63.

Bartoli G., Migon C. and Losno R. (2005) Atmospheric input of dissolved inorganic phosphorus and silicon to the coastal northwestern Mediterranean Sea: fluxes, variability and possible impact on phytoplankton dynamics. Deep Sea Res. I 52, 2005-2016. doi:10.1016/j.dsr.2005.06.006.

Benson B. B. and Krause D. (1984) The concentration and isotopic fractionation of oxygen dissolved in fresh water and seawater in equilibrium with the atmosphere. Limnol. Oceanogr. 29, 620632.

Béthoux J. P., Gentili B., Raunet J. and Tailliez D. (1990) Warming trend in the Western Mediterranean deep-water. Nature 347, 660-662.

Béthoux J. P., Morin P. and Ruiz-Pino D. P. (2002) Temporal trends in nutrient ratios: chemical evidence of Mediterranean ecosystem changes driven by human activity. Deep Sea Res. II 49, 2007-2016.

Béthoux J. P. and Migon C. (2009) The Mediterranean Sea: a case study for climatic and environmental changes. In $A S L O$ Aquatic Sciences Metting, Nice, January 25-30, 2009.

Black F. J., Conaway C. H. and Flegal A. R. (2009) Stability of dimethyl mercury in seawater and its conversion to monomethyl mercury. Environ. Sci. Technol. 43, 4056-4062. doi:10.1021/es9001218.

Cabana G. and Rasmussen J. B. (1994) Modeling food-chain structure and contaminant bioaccumulation using stable nitrogen isotopes. Nature 372, 255-257.

Chiavérini J. and Marty J. C. (2009) Abrupt increase of temperature and salinity in the WMDW at DYFAMED times-series station (NW Mediterranean Sea) in 2006: a response to decreasing rains? In ASLO Aquatic Science Meeting, Nice, France, January 25-30, 2009.

Claustre H. (1994) The trophic status of various oceanic provinces as revealed by phytoplankton pigment signatures. Limnol. Oceanogr. 39, 1206-1210.

Copin-Montégut C. (1988) Major elements of suspended particulate matter from the western Mediterranean Sea. Oceanol. Acta 11, 95-102 (special issue).

Copin-Montégut C. and Begovic M. (2002) Distributions of carbonate properties and oxygen along the water column $(0$ $2000 \mathrm{~m}$ ) in the central part of the NW Mediterranean Sea (Dyfamed site): influence of winter vertical mixing on air-sea $\mathrm{CO}_{2}$ and $\mathrm{O}_{2}$ exchanges. Deep Sea Res. II 49, 2049-2066.

Copin-Montégut G. and Avril B. (1993) Vertical distribution and temporal variation of dissolved organic carbon in the NorthWestern Mediterranean Sea. Deep Sea Res. I 40, 1963-1972.

Cossa D., Martin J. M. and Sanjuan J. (1994) Dimethylmercury formation in the Alboran Sea. Mar. Pollut. Bull. 28, 381-384.

Cossa D., Martin J. M., Takayanagi K. and Sanjuan J. (1997) The distribution and cycling of mercury species in the western Mediterranean. Deep Sea Res. II 44, 721-740.

Cossa D., Cotte-Krief M. H., Mason R. P. and BretaudeauSanjuan J. (2004) Total mercury in the water column near the shelf edge of the European continental margin. Mar. Chem. 90, 21-29.

Cossa D. and Coquery M. (2005) The Mediterranean mercury anomaly, a geochemical or a biological issue. In The Mediterranean Sea (ed. A. Saliot). In The Handbook of Environmental
Chemistry, vol. 5, Water Pollution, Part K. Springer-Verlag, Berlin/Heidelberg, pp. 177-208, 413p.

Cossa D., Averty B. and Pirrone N. (2009) The origin of methylmercury in open Mediterranean waters. Limnol. Oceanogr. 54, 837-844.

Cuny P., Marty J. C., Chiaverini J., Vescovali I., Raphel D. and Rontani J. F. (2002) One-year seasonal survey of the chlorophyll photodegradation process in the northwestern Mediterranean Sea. Deep Sea Res. II 49, 1987-2005.

Fisher N. S. (1985) Accumulation of metals by marine picoplankton. Mar. Biol. 87, 137-142.

Fitzgerald W. F., Lamborg C. H. and Hammerschmidt C. R. (2007) Marine biogeochemical cycling of mercury. Chem. Rev. 107, 641-662. doi:10.1021/cr050353m.

Gill G. A. and Fitzgerald W. F. (1985) Mercury sampling of open ocean water at the picomolar level. Deep Sea Res. 32, 287-297.

Guidi L., Stemmann L., Jackson G. A., Ibanez F., Claustre H., Legendre L., Picheral M. and Gorsky G. (2009) Effects of phytoplankton community on production, size and export of large aggregates: a world-ocean analysis. Limnol. Oceanogr. 54, 1951-1963.

Horvat M., Kotnik J., Logar M., Fajon V., Zvonaric T. and Pirrone N. (2003) Speciation of mercury in surface and deep-sea waters in the Mediterranean Sea. Atmos. Environ. 37, 93-108.

Kainz M. and Mazumder A. (2005) Effect of algal and bacterial diet on methyl mercury concentrations in zooplankton. Environ. Sci. Technol. 39, 1666-1672.

Karl D. M., Knauer G. A. and Martin J. H. (1988) Downward flux of particulate organic matter in the ocean: a particle decomposition paradox. Nature 332, 432-441.

Kotnik J., Horvat M., Tessier E., Ogrinc N., Monperrus M., Amouroux D., Fajon V., Gibicar D., Zizek S., Sprovieri F. and Pirrone N. (2007) Mercury speciation in surface and deep waters of the Mediterranean Sea. Mar. Chem. 107, 13-30.

Lee C., Armstrong R. A., Cochran J. K., Engel A., Fowler S. W., Goutx M., Masqué P., Miquel J. C., Peterson M., Tamburini C. and Wakeham S. (2009) MedFlux: investigations of particle flux in the twilight zone. Deep Sea Res. II 56, 1363-1368.

Lévy M., Memery L. and Andre J. M. (1998) Simulation of primary production and export fluxes in the Northwestern Mediterranean Sea. J. Mar. Res. 56, 197-238.

Marty J.-C. (2002) The DYFAMED time-series program (FrenchJGOFS). Deep Sea Res. II 49, 1963-1964.

Marty J.-C., Garcia N. and Raimbault P. (2008) Phytoplankton dynamics and primary production under late summer conditions in the NW Mediterranean Sea. Deep Sea Res. I 55, 11311149.

Marty J. C., Nicolas E., M J. C. and Fowler S. W. (1994) Particulate fluxes of organic compounds and their relationship to zooplankton fecal pellets in the northwestern Mediterranean Sea. Mar. Chem. 46, 387-405.

Marty J. C. and Chiavérini J. (2002) Seasonal and interannual variations in phytoplankton production at DYFAMED timeseries station, northwestern Mediterranean Sea. Deep Sea Res. II 49, 2017-2030.

Marty J. C., Chiavérini J., Pizay M. D. and Avril B. (2002) Seasonal and interannual dynamics of nutrients and phytoplankton pigments in the western Mediterranean Sea at the DYFAMED time-series station (1991-1999). Deep Sea Res. II 49, 1965-1985.

Marty J. C. and Chiavérini J. (2010) Hydrological changes in the Ligurian Sea (NW Mediterranean) Dyfamed site during 19952007 and biogeochemical consequences. Biogeosci. Discuss. 7, 1377-1406.

Mason R. P. and Fitzgerald W. F. (1990) Alkylmercury species in the Equatorial Pacific. Nature 347, 457-459. 
Mason R. P. and Fitzgerald W. F. (1993) The distribution and biogeochemical cycling of mercury in the Equatorial PacificOcean. Deep Sea Res. I 40, 1897-1924.

Mevel G., Vernet M., Goutx M. and Ghiglione J. F. (2008) Seasonal to hour variation scales in abundance and production of total and particle-attached bacteria in the open NW Mediterranean Sea (0-1000 m). Biogeosciences 5, 1573-1586.

Migon C. and Sandroni V. (1999) Phosphorus in rainwater: partitioning inputs and impact on the surface coastal ocean. Limnol. Oceanogr. 44, 1160-1165.

Migon C., Sandroni V., Marty J.-C., Gasser B. and Miquel J.-C. (2002) Transfer of atmospheric matter through the euphotic layer in the northwestern Mediterranean: seasonal pattern and driving forces. Deep Sea Res. II 49, 2125-2141.

Miquel J. C., Fowler S. W., La Rosa J. and Buat-Menard P. (1994) Dynamics of the downward flux of particles and carbon in the open Northwestern Mediterranean-Sea. Deep Sea Res. I 41, 243-261.

Miquel J. C., Martin J., Gasser B. and Marty J. C. (2009) Processes enhancing carbon export in the Mediterranean: results from a multi-year study. In ASLO Aquatic Sciences Meeting, Nice, January 25-30, 2009.

Monperrus M., Tessier E., Amouroux D., Leynaert A., Huonnic P. and Donard O. F. X. (2007) Mercury methylation, demethylation and reduction rates in coastal and marine surface waters of the Mediterranean Sea. Mar. Chem. 107, 49-63.

Morel F. M. M., Kraepiel A. M. L. and Amyot M. (1998) The chemical cycle and bioaccumulation of mercury. Ann. Rev. Ecol. Syst. 29, 543-566.

Niewiadomska K., Claustre H., Prieur L. and d'Ortenzio F. (2008) Submesoscale physical-biogeochemical coupling across the Ligurian Current (northwestern Mediterranean) using a biooptical glider. Limnol. Oceanogr. 53, 2210-2225.

Ogrinc N., Monperrus M., Kotnik J., Fajon V., Vidimova K., Amouroux D., Kocman D., Tessier E., Zizek S. and Horvat M. (2007) Distribution of mercury and methylmercury in deep-sea surficial sediments of the Mediterranean Sea. Mar. Chem. 107, $31-48$.

Parker J. L. and Bloom N. S. (2005) Preservation and storage techniques for low-level aqueous mercury speciation. Sci. Total Environ. 337, 253-263.

Ras J., Claustre H. and Uitz J. (2008) Spatial variability of phytoplankton pigment distributions in the Subtropical South Pacific Ocean: comparison between in situ and predicted data. Biogeosciences 5, 353-369.

Rassoulzadegan F. (1993) Protozoan patterns in the AzamAmmermann's bacteria-phytoplankton mutualism. In Trends in Microbial Ecology (eds. R. Guerrero and C. Pedros-Alio). Spanish Society for Microbiology, Barcelona, pp. 435-439.

Sournia A., Brylinski J. M., Dallot S., Lecorre P., Leveau M., Prieur L. and Froget C. (1990) Hydrological fronts off the coasts of France - a review. Oceanol. Acta 13, 413-438.
Stemmann L., Gorsky G., Marty J. C., Picheral M. and Miquel J. C. (2002) Four-year study of large-particle vertical distribution $(0-1000 \mathrm{~m})$ in the NW Mediterranean in relation to hydrology, phytoplankton, and vertical flux. Deep Sea Res. II 49, 2143 2162.

Stoichev T., Martin-Doimeadios R. C. R., Tessier E., Amouroux D. and Donard O. F. X. (2004) Improvement of analytical performances for mercury speciation by on-line derivatization, cryofocussing and atomic fluorescence spectrometry. Talanta 62, 433-438.

Sunderland E. M., Krabbenhoft D. P., Moreau J. W., Strode S. A. and Landing W. M. (2009) Mercury sources, distribution, and bioavailability in the North Pacific Ocean: insights from data and models. Global Biogeochem. Cycles 23, 14. doi:10.1029/ 2008gb003425, Gb2010.

Tamburini C., Garcin J., Ragot M. and Bianchi A. (2002) Biopolymer hydrolysis and bacterial production under ambient hydrostatic pressure through a $2000 \mathrm{~m}$ water column in the NW Mediterranean. Deep Sea Res. II 49, 2109-2123.

Tamburini C., Garcin J. and Bianchi A. (2003) Role of deep-sea bacteria in organic matter mineralization and adaptation to hydrostatic pressure conditions in the NW Mediterranean Sea. Aquat. Microb. Ecol. 32, 209-218.

Tanaka T. and Rassoulzadegan F. (2002) Full-depth profile (0$2000 \mathrm{~m}$ ) of bacteria, heterotrophic nanoflagellates and ciliates in the NW Mediterranean Sea: vertical partitioning of microbial trophic structures. Deep Sea Res. II 49, 2093-2107.

Tanaka T. and Rassoulzadegan F. (2004) Vertical and seasonal variations of bacterial abundance and production in the mesopelagic layer of the NW Mediterranean Sea: bottom-up and top-down controls. Deep Sea Res. I 51, 531-544.

Tholosan O., Garcin J. and Bianchi A. M. (1999) Effects of hydrostatic pressure on microbial activity through a $2000 \mathrm{~m}$ deep water column in the NW Mediterranean Sea. Mar. Ecol. Prog. Ser. 183, 49-57.

Uitz J., Claustre H., Morel A. and Hooker S. B. (2006) Vertical distribution of phytoplankton communities in open ocean: an assessment based on surface chlorophyll. J. Geophys. Res. 111, 23. doi:10.1029/2005jc003207, C08005.

Vidussi F., Claustre H., Manca B. B., Luchetta A. and Marty J. C. (2001) Phytoplankton pigment distribution in relation to upper thermocline circulation in the eastern Mediterranean Sea during winter. J. Geophys. Res. 106, 19939-19956.

Wakeham S. G., Lee C., Peterson M. L., Liu Z., Szlosek J., Putnam I. F. and Xue J. (2009) Organic biomarkers in the twilight zone: time series and settling velocity sediment traps during MedFlux. Deep Sea Res. II 56, 1437-1453.

Associate editor: Alfonso Mucci 